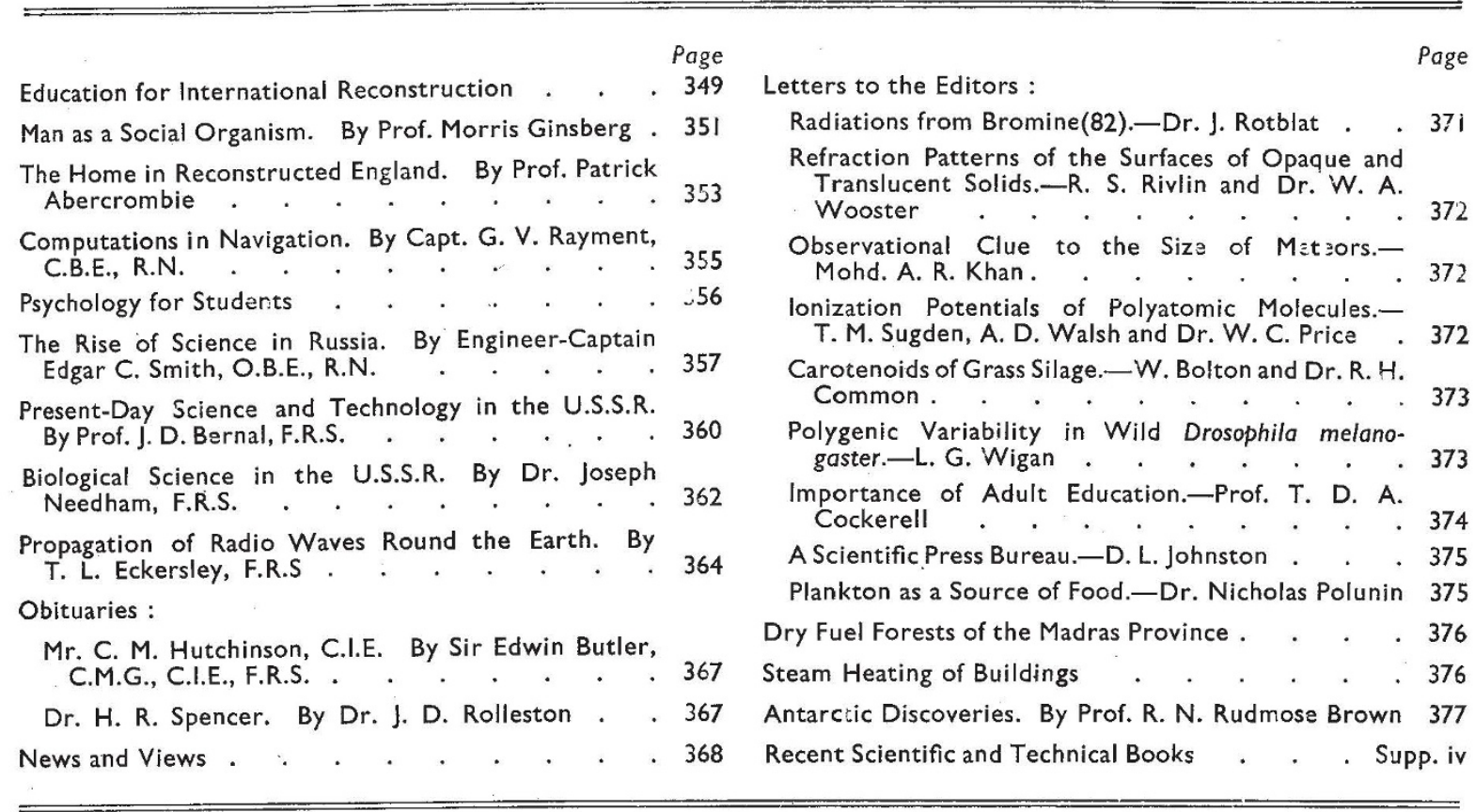

\title{
EDUCATION FOR INTERNATIONAL RECONSTRUCTION
}

$\mathrm{T}$ HE present phase of the War seems particularly appropriate for further consideration of the possibilities arising out of the unrest which is growing in the countries of Europe at present under Nazi control, Propaganda is obviously of high importance in this connexion, and the announcement that the Government has appointed a directorate of political warfare to co-ordinate the whole of our foreign propaganda indicates awareness of the urgency of the situation; the board will include representatives of the Foreign Office, Ministries of Economic Warfare and Information, and the British Council, and the B.B.C. and other bodies will co-operate. Three recent publications referred to below* make valuable contributions to the discussion of the subject.

Prof. Keeton attributes the failure of the attempt at world organization through the League of Nations to the absence of an international public opinion, and points out that to establish the machinery for international organization without such a public opinion would be to court failure a second time. International public opinion, however, does not grow of its own volition. It is

* The Case for an International University. By Prof. G. W. Keeton. Pp. 40. (London: C. A. Watts and Co., Itd., 1941.) 6d. net.

Ofrensive against Ger. Whar. By sebastian swafner. (Searchlight Books, No. 2.) Pp. 128. (London: Secker and Warburg, 1941.) 28. net. 1941.) primarily an educational process, and it is as a contribution to the formation of such an opinion that Prof. Keeton urges the formation of an international university.

The creation of an international solidarity sufficiently powerful to make international institutions an effective reality involves the use or development of an adequate technique, the abandonment of the indifference to the needs of human association which has been so common in democratic communities in recent years, and the establishment of some forum for the discussion and exposition of the methods to be used in establishing an international order. Developments such as the 'Round 'Table' discussions of the University of Chicago need to be taken up in Great Britain and widely extended, and an international university would have as one of its main tasks the organization of research into all those problems which arise in the achievement of a world order, and the publication of the results of such investigations.

An even greater task than research would be the teaching, both of the adult communities and of the youth, of those nations which supported the project. This is a task calling for much imagination and creative thinking as well as for careful organization, if we are to avoid the mistakes that have 
devitalized the adult education movement in Great Britain, and to foster the development, not of a hybrid internationalism, but of an ordered nationalism, seeking to establish the place of individual national cultures within the general pattern. Some of the work which has already been carried out in this field by the Committee of Intellectual Cooperation of the League of Nations has pointed the way, and the beginnings of an interchange of students and teachers already existed before the War.

What is now required is that these possibilities should be explored, not in an academic spirit, but with vigour and vision in full realization of the contribution they offer to the very founding of a new order. For that reason this task cannot be dismissed entirely until hostilities cease. The opportunities that lie to our hand must be seized and used as part of a great moral and spiritual offensive.

Although in his earlier book Sebastian Swaffner directed attention to the offensive value of an international academy, which could so easily be established in Great Britain now that there are so many émigré scholars in our midst, apart from a reference in Mr. Eden's speech of July 6 there have been few indications that the significance of the existence in London of a miniature Europe is realized. It would indeed be short-sighted policy if, in the recruitment of their services in our war effort, we overlooked these larger possibilities and failed to utilize their learning and skill in a direction which would demonstrate at once the shallowness of the Nazi pretence of a united Germany or Europe, and make so important a contribution to the preparation of a new European order.

In his "Offensive Against Germany", Swaffner says little about his earlier proposal for such an international academy or university. $\mathrm{He}$ is concerned primarily with what he terms the moralpsychological strategy of the War, of which so far we have allowed the Nazis the monopoly. Our attention to morale has been largely the defensive one of maintaining that of our own people, rather than the offensive one of breaking down the morale of our enemy. It is Swaffner's analysis of the weaknesses and vulnerability of German morale, of the methods and prospects of attack rather than his own plan of attack, that give value to his book. It is directly complementary to the P E P broadsheet, for the strategy of political warfare as well as the tactics used to attack the enemy's morale must be largely influenced by our view of what solutions of the problem of Germany are possible.

The P E P broadsheet starts with an analysis of the salient features in the current German situation, pointing out that the concentrated drive of the earlier phase of Nazism is becoming dissipated as an inevitable result of the extension of the Nazi campaign from a limited field where the Germans are in a majority to the wider European field in which they are outnumbered by at least four to one. Simultaneously, the clear-cut ideology and sense of mission developed in a closed artificial atmosphere is becoming confused or even inhibited, while the aggressive spirit of indicting an indefensible old order is giving place to a defensive attitude towards an even less defensible New Order. Strategically, these developments have led to immensely extended and increasingly costly and vulnerable lines of communication. Politically, they involve the inclusion within the German system of a majority of inhabitants non-German in sympathy and increasingly anti-Nazi in attitude. The need for absorbing and restarting a vast range of industries built up in competition with German industry throws a strain on the economic system comparable with that which in the administrative sphere has involved a sacrifice of much of the homogeneity and efficiency achieved by the Nazi system.

No violent revolutionary movement within Germany is to be looked for before or even after a military defeat, but the chances are strongly against successful Nazification of the territories occupied by Germany during the last eighteen months. The chances, on the contrary, are strongly in favour of growing spontaneous resistance movements in neighbouring occupied or threatened territories contributing to German defeats through sabotage, passive resistance and ideological means. The broadsheet concludes that development of these movements, rather than any development within Germany, is likely to shape the future social pattern of a defeated Germany, which must draw heavily from outside to replace the shattered influences now temporarily superseded by Nazism.

Visualizing the immediate post-war period, the P E P broadsheet suggests that there should be four stages in Germany as a whole or in any part of it. First the termination of Nazi power either by driving out the armed forces and Gestapo or by. their surrender and demobilization. Then come the establishment of emergency military administration by occupying forces, and the prompt creation of as strong a bulwark against disorders and the lawless seizures of territory as conditions may require. The transfer of all civil affairs to a Reconstruction Commission, including American and of other independent members, as well as political, economic and medical branches, follows, and finally the gradual development of appropriate German self-governing bodies and the gradual transfer of power to them.

Disintegration of a defeated Germany is likely to be much more complete in the present war than 
in 1918, owing to the destruction of alternative nuclei and to other factors, but there is no reason why we should not let this disintegration run its course. The bulwark for the protection of Europe as a whole should be formed at first exclusively of non-German forces, and the military occupation of Germany is essential as the first stage in a carefully planned and directed re-creation of German institutions as an essential part of European reconstruction. Successful post-war treatment of Germany depends on the reconciliation of two apparently contradictory propositions: the German people can never again be trusted not to abuse their strength by trying to trample on weaker neighbours, and any settlement which discriminates against and refuses to trust the German people contains the seeds of another German war.

The P E P broadsheet concludes accordingly that Europe must be organized so as to divorce national structures from military and industrial power. This organization must be backed by world control of raw materials and communications, with the object not only of facilitating economic expansion, but also of thwarting policies of autarchy and militarism by automatic sanctions. The post-war settlement of Europe should be along the lines of the British Commonwealth rather than a written constitution, and within this framework the extent of a future German State should be decided by the unfettered choice of the peoples to be included in it. Establishment of social and economic opportunity and security is the only practical basis of enduring peace, and the winning of the peace depends on Britain holding the initiative and using it in the long-term interests of the European majority, and in the convergent interests of the United States and the Dominions, whose cooperation would be needed at every point. Behind this policy there must be visible British sea- and air-power, backed by war industries, maintaining stores instantly available to threatened countries on lease-lend principles, and by availability of strategic bases.

It is against this background that the value of the meeting between President Roosevelt and Mr. Churchill and the Charter of the Atlantic which issued from it must be assessed. The manner in which the eight points of the Charter meet the conclusions drawn from the PEP analysis of the German problem justifies the view that the Charter is a political weapon of the first order. The whole circumstances in which the meeting was held dealt such blows to German claims and propaganda that it can well be hailed as the launching of the moral and political offensive for which an important section of opinion in Great Britain has been pressing. If these hopes and expectations are justified, and the Government seizes the opportunities now opening in this field, and by the effort and thought which it devotes, not sporadically but continuously and systematically, to political warfare, we may well find in this meeting and Charter the token that the path to the New Order for which we strive may be shorter and less tortuous than anything which the military, naval or air situation would warrant our believing.

\section{MAN AS A SOCIAL ORGANISM}

\section{Human Nature and the Social Order}

By E. L. Thorndike. Pp. $\mathrm{xx}+1020$. (New York : The Macmillan Company, 1940.) 18s. net.

"WHAT can men do, what do they do, and what do they want to do ?"--these are the questions that Prof. Thorndike seeks to answer in a very comprehensive and elaborate treatise. His undertaking is inspired by the belief that man has the possibility of almost complete control of his fate if only he will be guided by science, and that his failures are attributable to ignorance or folly. The main approach is through biological psychology, but all the social sciences are appealed to and utilized in an effort to deal with the human problem as a whole. The relative immaturity of the sciences dealing with man is continually stressed, but it is claimed that they provide a body of facts and principles which are "far above zero knowledge", and that even now they are capable of affording valuable guidance in the shaping of public policy.

The picture that Prof. Thorndike draws of human nature and its possibilities is based on a view of mind reached by him in his well-known and extensive studies of animal and human behaviour. Man is depicted as a bundle of inborn capacities and wants which are gradually organized by the action of the environment. The underlying conception is on the whole mechanistic. Man is a network of connexions between stimuli and responses operating in the service of a group of wants. A structure is built up as the result of the strengthening of connexions through repetition and the experience of satisfaction and annoyance. It is assumed that for every variation in response 